and social gifts". No Savilian professor has had the distinction of representing the University in Parliament; but according to G. W. E. Russell, in 1879, "The Liberals by a strange perversity of choice brought forward Professor Henry Smith, a mathematical genius of the highest rank but so half-hearted a politician that E. A. Freeman said that he was better qualified to sit as member for Laodicea in the Parliament of Asia Minor".

Smith had been appointed to the chair of geometry at the age of thirty-four; his successor, James Joseph Sylvester, was twice that age, having been born in 1814. A Wrangler in 1837, his Jewish parentage had debarred him from a degree, and before being appointed to Oxford he had held professorial posts in London, Woolwich, Virginia and Baltimore. He continued to lecture at Oxford until about 1892 , when through his failing eyesight, William Esson was appointed his deputy and eventually his successor. A Fellow of Merton College since 1860, Esson at one time collaborated with the distinguished chemist, A. G. Vernon Harcourt, and held University offices. To one student Esson's mission seemed to be "to illuminate mathematically the obscure records of chemical velocities". After teaching for a very long period, he died in 1916, and in 1919 was succeeded by Prof. G. H. Hardy, who died at Cambridge so recently as December 1, 1947. The Times, in its obituary of him, said that he was "perhaps the greatest pure mathematician of his day-he would certainly be ranked in the first half-dozen-and one of the most familiar 'characters', both of Oxford and of Cambridge. ..." A tribute to Hardy was paid by Prof. M. H. A. Newman in a broadcast, printed in The Listener of January 22 1948. In 1931, Hardy had returned to Cambridge and Prof. E. C. Titchmarsh succeeded to the Oxford chair, having previously held the chair of pure mathematics at Liverpool.

These brief and all too meagre notes will perhaps give some idea of the benefits which have accrued to science in Oxford through the far-sighted action of Savile. It is possible that Oxford can claim a longer list of such benefactors than any other university in the world; Her colleges, halls, chapels, libraries and museums, her professorships, lectureships and scholarships recall the names of kings and nobles, chancellors and prelates, teachers and scholars and men of many degrees. To the visitor to the city it might be said: "If you wish to see their monuments look around". Their influence has spread throughout the world; but among them all, few deserve to be remembered more than Sir Henry Savile, whose memorial, like that of his close friend Thomas Bodley, is to be seen in the chapel of Merton College, which he served so faithfully and so long.

$$
60 \%
$$

\section{AFRICAN REGIONAL SCIENTIFIC CONFERENCE}

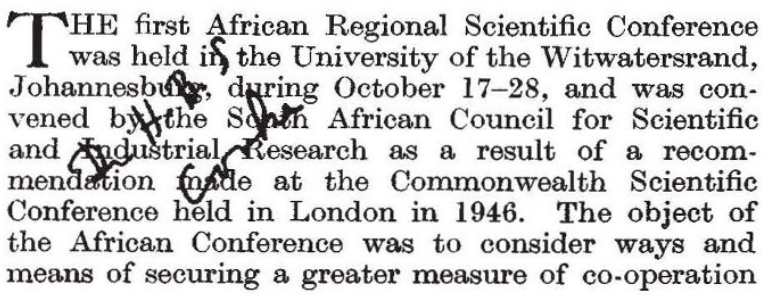

between the different territories in Africa south of the Sahara in problems involving research of a longterm nature. There were 107 delegates, representing the various African territories concerned and the Metropolitan-Governments with direct interests in this part of Africa, present at the Conference. There were also observers from the World Health Organisation, Food and Agriculture Organisation, United States National Research Council, United Nations Educational, Scientific and Cultural Organisation, and the Overseas Food Corporation.

The Belgian delegation was led by Dr. P. Staner, of the Colonial Ministry, Brussels, the French delegation by Prof. J. Millot, director of the Institute for Scientific Research in Madagascar, the Portuguese delegation by Dr. A. A. E. M. Correia, director of the Colonial Training College of Portugal, the United Kingdom delegation by Sir Ben Lockspeiser, secretary of the Department of Scientific and Industrial Research, and the South African delegation by Dr. B. F. J. Schonland, president of the South African Council for Scientific and Industrial Research.

During the period of the Conference, the delegates were the guests of the Union Government. They were entertained at a number of functions and were given the opportunity of visiting some of the scientific institutes in the Johannesburg and Pretoria areas. The University of the Witwatersrand conferred honorary degrees upon the leaders of the various national delegations. At the conclusion of the main business of the Conference, delegates were taken on a short tour of the wild-life sanctuary in the Eastern Transvaal, the Kruger National Park, where they saw a wide variety of animals.

The Conference was officially opened by the Prime Minister of the Union of South Africa, Dr. D. F. Malan, and his opening address was followed by messages of welcome from the heads of the various delegations. On the proposal of Sir Ben Lockspeiser, Dr. P. J. du Toit, formerly director of the Onderstepoort Veterinary Research Institute and now deputy president of the South African Council for Scientific and Industrial Research, was unanimously elected as president of the Conference. This post he filled with great tact and skill, which contributed greatly to the successful outcome of the Conference.

The first two days were devoted to plenary sessions at which delegates from the various territories delivered statements on the general organisation and research in the various countries and regions. Thereafter the Conference was split into six Sections, as follows: (A) physical environment; (B) soils and plants; (C) zoology and animal industry; (D) health and medical research; (E) social research; (F) technology. Chairmen elected for each Section were: (A) Dr. S. H. Haughton, geological adviser to the Union Government; (B) Prof. A. Quintanilha, director of cotton research in Portuguese East Africa; (C) Prof. L. van den Berghe, director of the Institute for Scientific Research in Central Africa (Belgian Congo); (D) Sir Edward Mellanby, secretary of the Medical Research Council in Great Britain and chairman of the Colonial Medical Research Commission; (E) Prof. T. Monod, director of the French Institute for Black Africa at Dakar; and (F) Dr. E. B. Worthington, of East Africa.

Within the sectional meetings, spread over six very full days, 118 papers by delegates and other expert contributors were presented. The papers had been printed in advance, and were only very briefly summarized by the authors at each meeting, the principal 
object of the meetings being the discussion which followed. The general scope of the papers and discussions covered surveys and maps; geology and geophysics; meteorology and hydrology; soils and soil conservation; botany and plant industry; forestry; zoology; animal industry; the biology of water; health ; medical research ; social research ; building research; road research; industrial research; and library and information services.

It was apparent from the outset that the delegates from the various countries were meeting on common ground of great mutual interest and that they shared the firm conviction that co-ordination of scientific effort in Africa south of the Sahara was a vital need. It was also obvious that each territory felt very acutely the shortage of trained scientific workers, and this matter cropped up repeatedly in discussions on a wide variety of topics. In view particularly of the small number of highly trained men of science in Africa, the wastage of scientific man-power in the performance of routine duties was generally deplored. Although no specific resolution on this matter was brought before the plenary session, it was felt that the expenditure of a relatively small amount of additional money on the provision of laboratory assistants would alone result in a greatly increased output of scientific work.

Another matter which intruded itself into discussions on many occasions was the need for compiling and comparing, in the form of maps, a large number of facts of importance for progress in scientific research and in the economic development of Africa. This culminated in a resolution to the effect that the Conference recommends that each main region in Africa should arrange for the production of smallscale maps or atlases - where necessary on a basis of inter-State collaboration-in order to provide information on the physical environment (geological, climatological, hydrological, etc.), the biological environment (vegetation, fauna, insects as vectors of disease, etc.), and human facts (race pathology, demography, ethnic groups, languages, communications, economic factors, etc.). This work should, if possible, be co-ordinated and produced on a uniform system so that the maps which result could provide a scientific outline of Africa.

The desirability of achieving uniformity in ordinary maps of Africa south of the Sahara was the subject of another resolution adopted at the plenary session. It was considered that, so far as possible, map projections, sheet boundaries, scales and conventional symbols for use on maps should be uniform in order that maps of adjacent territories might be directly comparable. It was also suggested that the figure of the earth used in geodetic calculations should be uniformly agreed. The attention of governments was directed in another resolution to the considerable benefits to be derived by many branches of scientific research in Africa from complete air photography of their respective territories, quite apart from the use to which air photographs could be put in the production of topographic maps.

Resolutions from Section A which were unani. mously adopted at the final plenary session include, in addition to the ones already mentioned above, a resolution calling for the establishment of a regional bureau for geological and mineral research to serve the territories in Africa south of the Sahara as an organisation for collecting and disseminating information on the aspects of those subjects which are of common interest, and to act as a co-ordinating agency in the field of geological research. It was recommended also that palæontological research in Africa should be one of the subjects to be dealt with by the proposed bureau.

In the field of geophysics the Conference considered that provision of more instruments is necessary for the further study of such features as the seismicity of the African continent and gravitational variations within its boundaries. The extension of ionospheric and magnetic observations is desirable, as well as collaboration in the study of radio noise levels and the physical constants of the ground at radio frequencies. In meteorology it was considered that further co-ordination might be effected through an organisation linked with the African Regional Commission of the International Meteorological Organisation.

Presented originally as a recommendation from Section A, but overlapping with suggestions from several other Sections, a composite resolution on hydrology was adopted by the Conference. It was urged that steps be taken to organise the systematic collection and publication of all stream-discharge and related records, and to expand long-term hydrological research in the widest sense so as to include investiga. tions on the influence of agricultural, piscicultural and forestry forms of land use on infiltration, evaporation, transpiration, run-off, stream-discharge and ground water, as well as their effects on health.

Resolutions adopted on the recommendation of Section B covered several aspects of pure and applied agricultural and botanical research. The setting up of an inter-African bureau of information on the conservation and utilization of the soil, arising out of the 1948 Goma Conference, and the establishment of an inter-African pedological survey at Yangambi in the Belgian Congo, were warmly approved. It was urged that, as increasing demands for food must lead to the increasing expansion of agriculture into the semi-arid regions of Africa, steps be taken to secure an early assessment of relevant knowledge available in the several branches of the sciences concerned with research on agriculture in such regions. The recogni. tion of the importance of soil microbiology in soil fertility problems led to the recommendation that adequate facilities for fundamental soil microbio. logical studies and for the training of microbiologists in African territories be established. Adequate facilities were also required for fundamental studies on plant physiology and investigations on fungi and plant nematodes. Intensified research into the wastage of fruit through decay between production and con. sumption was also urged, and it was recommended that research be conducted with the view of making possible the expansion of deciduous fruit production in the inter-tropical zone. The Conference also stressed the urgent necessity for intensifying botanical research in taxonomy, ecology and plant geography ir order that fundamental information essential to research workers in applied science, now ofter inadequate or lacking, should become available for the economic development of the continent.

In Section $\mathrm{C}$ a similar need for basic taxonomic and ecological research as a foundation for other work was the subject of an independent resolution, also adopted by the Conference. It was considered desirable that steps be taken to compile a list of types and paratypes of zoological specimens in Africa, together with information concerning the places where they are housed. The ringing and marking of mammals, birds and fishes should be undertaken 
on a large scale in order that studies of migration might be made. A well-planned survey of ticks and other disease vectors in Africa south of the Sahara should also be undertaken, as this affects both human and animal life.

More intensive and extensive investigations on the vast problem of poisoning by plants was also considered necessary. The Conference recommended, too, that an animal nutrition survey be initiated in view of present inadequacy of knowledge regarding nutritional matters and other factors which result in devastating stock losses in the continent. Because of certain present limitations in the development of animal production in Africa, it was considered necessary that the fishing resources be developed as an additional source of animal protein.

The subject of wild-life protection aroused widespread discussion during the meeting, and resulted in a unanimous resolution from all Sections that biologists should play a prominent part in the conservation of wild plant and animal life in all African States. It was urged that a central body for the coordination of wild-life research in Africa be established, and that a mammalian survey be initiated as soon as possible. The Conference also requested that at least one centre be created, preferably in each region, where research teams could carry out comprehensive and fundamental work on the safeguarding of the natural resources of soils, water and fertility at every level of plant production that modern developments may demand.

Of the recommendations from Section D, those adopted by the Conference concerned malnutrition, vector-borne diseases and environmental studies. It was recommended that every facility be given to expanding work on investigating malnutrition in human beings, more especially by ensuring closer co-ordination and consultation between research workers. This was considered vitally important, since malnutrition appears to be a widespread cause of subnormal health and development in Africa. It is also desirable that long-term research be undertaken to discover the potentialities of the African in general, and this can best be done by regional teams of scientific workers with a central committee to co-ordinate their research. Attention was directed to the need for a proper study of the African environment and its influence on human health, and the adaptation and acclimatization to such an environment of the different races living in Africa. The Conference recognized the need for providing facilities for special postgraduate training on research in African diseases and recommended that a specialist conference be called to consider problems of malaria research and control. Additional research is also necessary on bilharziasis and virus and rickettsial diseases.

Acting on recommendations from Section E, the Conference considered that investigations on the social sciences should be undertaken, mainly on territorial lines, in which the co-operation of all existing organisations should be ensured. A social. research liaison organisation is needed to keep the various organisations informed of activities, to coordinate research projects, and to facilitate the movements of research workers between the various regions ; psychological studies and social surveys are also necessary. It was pointed out that attention should be paid to uniformity of sampling methods and uniformity of bases for the collection of statistical information. The Conference suggested that, in addition, a demographic committee be set up in order to co-ordinate and encourage demographic surveys. Also from Section E came a resolution which resulted in the Conference endorsing the resolution passed at the first Pan-African Congress on Prehistory held at Nairobi in 1947, when matters relating to the need for archæological surveys and the preservation and scientific excavation of prehistoric and other archæological sites were dealt with. The Conference stressed the need for intensified explora. tion with scientific support, and the preservation of prehistoric sites for systematic study and as 'museums on the spot'.

The recommendations from Section $\mathrm{F}$ were concerned with a variety of technological problems and for the most part emphasized special needs which could be investigated on territorial lines with the assistance of co-ordinating bodies, rather than with recommendations for the setting up of new organisations. Attention was directed to the importance of the problems of water pollution in tropical waters and the need both for further research and for the interchange of information. Fisheries research and fish technology could take advantage of existing or proposed organisations; but there is urgent need for collaboration in the collection of fishery statistics. More investigation is desirable on the technological problems of utilizing phosphate rocks for the production of fertilizers. Research in all the technical and economic aspects of road planning and road construction and maintenance is desirable, and special attention might advantageously be given to the problems of low-cost roads. It was suggested that a meeting of specialists should be convened to consider road research matters in the near future.

The establishment of processing and other indus. tries in tropical Africa is becoming urgent, and the lack of much basic information and sound industrial research in Africa is hampering the effective expansion of industry. The Conference also emphasized the importance of good housing, and directed attention to the need for uniformity of methods in assessing climate, since this is a basic factor in the design of buildings. There is also a demand for research into the behaviour of building materials under African conditions and a need for the establishment of local industries for the production of building materials.

Another resolution which was enthusiastically adopted stressed the necessity for adequate library and information services to meet the requirements of men of science in Africa, and suggested the preparation of a directory of library and documentation centres in Africa and the compilation of a unified list of the holdings of scientific and technical journals in African libraries. It was also suggested that a number of regional photographic units should be set up for the purpose of making single copies of articles from scientific journals. A related resolution advocated that scientific papers in English or French might advantageously include summaries in the other language.

During the course of the discussions in the various Sections, the steering committee of the Conference, comprising the president, the leaders of the delegations and the chairmen of Sections. developed a scheme which was ultimately adopted with enthusiasm by the plenary session. The Conference recom. mended the establishment of a scientific council for Africa south of the Sahara as an advisory and consultative body composed of men of science representing both the subjects and the regions concerned. 
The functions of the council, which should be exercised in full co-operation with the specialist bureaux and other inter-territorial organisations, would be to encourage research workers and establish contacts between them, and to study what research projects of common interest could be usefully suggested to governments, research agencies or universities. Other aims of the council would be: to endeavour to facilitate the exchange and movement of scientific workers between different territories and to promote liaison between inter-government scientific bureaux or other bodies; to arrange for the compilation and distribution of information of general value concerning the locations of scientific workers, scientific equipment and specialist libraries; to foster, in respect of each of the major scientific subjects, the creation, in Africa, of centres of specialist documentation; to convene, with the consent of the Governments concerned, periodic conferences of a general scientific character and facilitate meetings of groups of specialists; and to submit recommendations to the Metropolitan Governments concerned in order to secure joint administrative action through a proposed inter-government committee for technical collaboration.

It is not intended that the proposed scientific council for Africa would itself establish any institutions or laboratories, or would itself actively direct research programmes; its main function would be to obtain a broad view of what research is being undertaken in Africa in order to minimize unnecessary overlap of effort and co-ordinate the work. Such an organisation would draw its strength from periodic conferences and meetings between scientific workers, but at the same time would ensure that such conferences are arranged on a rational plan with due regard to the expense involved. It is not anticipated that a large staff would be required, and the moving force of the council should be provided by a chairman able to give his whole time to the new organisation and direct a small personal secretariat.

The Conference suggested that the first chairman should be nominated for two years by agreement between the Metropolitan Governments, and stated that it would be happy to see Dr. P. J. du Toit nominated to this post. It also recommended that the governments concerned should establish, as soon as possible, a commission which might consist largely of members of the steering committee of the Conference to give shape to the proposal now put forward and to ensure its realization. It is felt that, should this council come into being, it will mark a major step in the progress of scientific research in Africa south of the Sahara.

H. B. S. COOKE

3)t6

\section{INSECT FLIGHT AND DISTBIBUTION}

$\mathrm{T}$ HE pattern of the geographical distribution of insects is ver varied; but among the widely distributed pecie we can recognize easily two types. First, the spedies which develops many local or geographical lees, yoh as the swallow-tail butterfly (P Qjitio machaon) 2 fd the apollo butterfly (Parnasstus apollo) in Europe; and secondly, the species which has little or no geographical variation over very large areas, such as certain locusts or the painted-lady butterfly (Pyrameis cardui). This latter type of distribution indicates a population within the area of which there are few natural barriers, and within which there is a continual mixing of individuals. It is associated with species which have great powers of movement; and this movement can be either active and deliberate, as in the migration of locusts, or passive, due to distribution by air currents, as in the Aphidx and other small insects. By either of these methods, large numbers of individuals can move hundreds of miles.

At the recent British Association meeting at Newcastle upon Tyne, Section D (Zoology) held an afternoon session devoted to these problems of insect flight and distribution. Dr. C. B. Williams opened the discussion with an account of the deliberate migrations of insects. This type of movement is found chiefly in the larger insects, and particularly in locusts, moths and butterflies, and in dragonflies and beetles (especially the Coccinellidæ). As a result of these movements, many millions of individuals belonging to hundreds of species regularly move hundreds of miles, and occasionally more than a thousand miles. Inland seas like the Mediterranean are regularly crossed by millions of insects. In the British butterfly fauna of sixty-eight species, about one-quarter is known to cross the Channel or the North Sea each year or at more irregular intervals. One of the greatest migrants known in the Lepidoptera is the monarch butterfly (Danaus plexippus) of North America, which flies from southern Canada to the Gulf States and to southern California every autumn, and then, after a period of semi-hibernation in the south, flies north again in the spring. This double flight of this species may well cover more than two thousand miles. Another great migrant, the painted-lady butterfly (Pyrameis cardui), flies from North Africa through Europe each spring, and sometimes reaches Iceland, a distance of nearly 1,500 miles. At the other side of the Atlantic, the same species, indistinguishable even as a race, flies in a similar way in the spring from western Mexico north. ward and eastward to cover in some years most of the United States and southern Canada.

Students of insect distribution must thus recognize that many species of insects may, by their own deliberate movements, be spread regularly over dis. tances of more than a thousand miles, and may reach oceanic islands and other isolated localities ; so that in such circumstances the setting up of a local race or a special gene-complex is almost impossible. Only in the Australian and New Zealand area is the local race of the painted-lady butterfly ( $P$. cardui kershawi) distinguishable from those of the rest of its almost world-wide range. From an economic point of view, the control of insect pests which are capable of long. distance migration in great numbers brings quite different problems from those of the comparatively sedentary species.

In the next paper, Prof. A. C. Hardy gave an account of his early work in trapping insects in the upper air by means of nets hanging from kites and towers on land, and from the mast-heads of ships crossing the North Sea. The insects thus caught are nearly all small, such as Aphidæ, Chalcidæ, and other small Hymenoptera, beetles (especially Staphyl. inidæ) and occasionally small moths and lace-wings (Chrysopidæ). The number of insects over land is greatest near the ground and falls off at first rapidly as the level of trapping is raised; but small numbers were caught at heights above a thousand feet.

Most of the trapping over the North Sea was done by nets flown at mast-head when the ships were more 